\title{
Russian parliament's funding plans run into budget realities
}

Moscow. The State Duma, the lower chamber of the Russian parliament, has voted almost unanimously to increase the national budget for science and education next year by 15,250 billion roubles (US\$3.05 billion) - a rise of 60 per cent. But the rise is certain to be rejected by the parliament's upper chamber and President Boris Yeltsin.

The rise was put forward in an amendment to the budget bill by the committee on science and education, headed by Ivan Melnikov of the Communist Party. Oleg Smolin, deputy chairman of the committee, suggested that the extra money could be taken from companies "that enjoy privileges and favourable conditions".

But the Duma's budget committee objected to the amendment because only 70 per cent of the income for the overall federal budget could be met. Oksana Dmitrieva, chairwoman of the budget committee, called the amendment "the budget Bacchanalia". She said it was a populist gesture, like many made during the recent presidential election campaign, and that it was illegal to allocate increased financing without saying where the funds would come from.

Gennadi Kulik (Agrarian Party) and Yuri Voronin (Communist), both deputy chairmen of the budget committee, reminded the deputies that the law concerned had never been violated, and that it allowed the government to limit inflation. The Duma should either alter the law or follow it, they said. If no additional money could be found, the amendment would increase the budget deficit.

But the Speaker of the Duma, Gennadi Seleznev (Communist), dismissed these warnings as "formalities", while one Communist deputy said that, if it had not been for the expenditure on presidential elections, the money for science and education could easily have been found.

The budget committee suggested ways to provide substantial support for science and education without violating the budget. For example, it proposed that funds for science and education should be included in the 'protected' areas of the budget, to be met under any circumstances; that the government should compensate scientists and educationalists for losses suffered since it failed to increase their salaries as promised by its decree at the end of last year; and that expenditure should be indexlinked each quarter of the year if inflation proved higher than anticipated.

But the deputies rejected all but the last of these measures. They approved the amendment suggested by the committee on science and education by 235 to 2 , with 17 abstentions.

Carl Levitin

\section{Social needs proposed as priority for EU research}

Munich. The European Union (EU)'s Fifth Framework Programme for research (FP5), to be launched in 1999, should focus more on social needs than the current programme (FP4), according to a discussion paper prepared under the auspices of Edith Cresson, the research commissioner.

The paper, which was approved last week by the full commission and presented to the Council of Ministers, says that FP5 should be organized around a limited set of objectives, ensuring that these meet the social and economic needs of European citizens.

This indicates a shift in the commission's approach to its research programmes, which currently cost an average of ECU2.6 billion (US $\$ 3.2$ billion) a year, and which have until recently been dominated by industrial needs. Although these needs remain fundamental, the commission is now also stressing that research should have a direct mpact on people's lives.

The discussion document is being widely distributed to member states and basic and

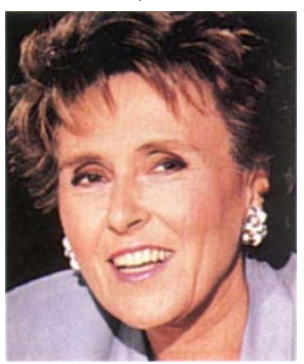

Cresson: FP5 should improve people's lives. industrial research organizations. According to one of its co-authors, Jack Matthey, a policy expert in Cresson's office, it will "be used as a basis for wide reflection" before the commission makes its final proposal on the content and operation of FP5 to the Council of Ministers and the European Parliament next spring.

The three broad research areas that the commission proposes throw up few surprises. The first, under the heading "Unlocking the resources of the living world and the ecosystem", would include "acquisition and utilization of knowledge about fundamental mechanisms affecting human life, especially in the fields of health and food".

The second, "Creating a user-friendly information system", covers aspects of advanced communication technologies that meet the needs of industry and society. Priorities would include mechanisms for facilitating access to information and helping to preserve linguistic diversity.

The third area is "Promoting competitive and sustainable growth". This would cover industrial production methods that take into account the full life-cycle of a product including waste management - as well as the management of energy, transport, agriculture and forestry.

The paper also proposes three additional activities to accompany the main research programmes. "Improving human potential" would cover training and mobility, the promotion of a European science prize, and a socio-economic programme to analyse the full social impact of research activities. The second activity would be designed to increase the participation of small businesses in FP5, for example by tailoring procedures more closely to their needs and by helping to establish links with venture capital companies.

The third activity would be to foster international links with European research, not only with non-EU industrial countries and the emerging economies of Asia, but also with central and eastern European countries that are expected to join the union in the near future.

According to Matthey, the paper is intended primarily to indicate the commission's general approach to FP5. Its eventual proposals on the content of the research will be based on discussions with interested parties over the next few months, he says. "We will continue to consider not only the industrial point of view, but also the environmental and social points of view."

Under the rules of the Maastricht Treaty, the Framework programme requires the unanimous vote of the EU's 15 member states and majority approval by the European Parliament. Commission officials argue that early consensus is the only pragmatic way forward. They also acknowledge that the commission's perceived lack of transparency and the inflexibility of its programmes are widely criticized; the document makes improved user-friendliness a priority.

The commission has in fact already made significant moves in this direction, for example by publishing details of its research programmes more widely, and simplifying application procedures. Ironically, this is held partly responsible for the heavy oversubscription of Framework programmes.

Further proposals aimed at improving the management of research programmes include the development of more immediate monitoring procedures, speeding up the selection of projects and simplifying the procedures involved in implementing programmes - by reducing the number of committees involved, for example.

The commission wants to encourage greater cooperation between member states by using more of the funding mechanisms available under the Maastricht Treaty. It would, for example, like to be able to supplement some activities of national research organizations, and to restrict some FP5 programmes to only a few member states, an approach known as 'variable geometry'.

Alison Abbott 